\title{
CONVERSES OF JENSEN'S OPERATOR INEQUALITY
}

\author{
JadRAnKa MićIĆ, Josip PeČARIĆ AND Yuki SeO
}

Abstract. We give a generalization of converses of Jensen's operator inequality for fields of positive linear mappings $\left(\phi_{t}\right)_{t \in T}$ such that $\int_{T} \phi_{t}(\mathbf{1}) d \mu(t)=k \mathbf{1}$ for some positive scalar $k$. We consider different types of converse inequalities.

Mathematics subject classification (2010): 47A63, 47A64.

Keywords and phrases: Converses of Jensen's operator inequality, convex function, Mond-Pečarić method, power functions, power means.

\section{REFERENCES}

[1] M. D. CHoI, A Schwarz inequality for positive linear maps on $C^{*}$-algebras, Illinois J. Math., 18 (1974) 565-574.

[2] Ch. Davis, A Schwarz inequality for convex operator functions, Proc. Amer. Math. Soc., 8 (1957), $42-44$.

[3] R. Drnovšek, T. Kosem, Inequalities between $f(\|A\|)$ and $\|f(|A|)\|$, Math. Inequal. Appl., 8 (2005), 1-6.

[4] J. I. Fujit, M. NAKAmura, J. PeČARIĆ AND Y. SEO, Bounds for the ratio and difference between parallel sum and series via Mond-Pečarić method, Math. Inequal. Appl., 9 (2006), 749-759.

[5] F. Hansen and G. K. Pedersen, Jensen's operator inequality, Bull. London Math. Soc., 35 (2003), $553-564$.

[6] T. Furuta, J. Mićić Hot, J. PeČarić And Y. SeO, Mond-Pečarić method in operator inequalities, Monographs in Inequalities 1, Element, Zagreb, 2005.

[7] F. HANSEN, J. PeČARIĆ AND I. PERIĆ, Jensen's operator inequality and it's converses, Math. Scand., 100 (2007), 61-73.

[8] J. MićIĆ AND J. PeČARIĆ, Order among power means of positive operators, II, Sci. Math. Japon. Online (2009), 677-693.

[9] J.Mićıć, Y.Seo, S.-E.TAKahasi And M.Tominaga, Inequalities of Furuta and Mond-Pečarić, Math. Inequal. Appl., 2 (1999), 83-111.

[10] B. Mond AND J. E. PEČARIĆ, Converses of Jensen's inequality for linear maps of operators, Analele Universit. din Timişoara, Seria Math.-Inform., XXXI, 2 (1993), 223-228.

[11] B. MOND AND J. PEČARIĆ, Converses of Jensen's inequality for several operators, Revue d'Analyse Numer. et de Thé orie de l'Approxim., 23 (1994), 179-183.

[12] B. Mond AND J. E. PEČARIĆ, Bounds for Jensen's inequality for several operators, Houston J. Math., 20, 4 (1994), 645-651.

[13] W. F. Stinespring, Positive functions on $C^{*}$-algebras, Proc. Amer. Math. Soc., 6 (1955), 211-216. 